\title{
Kedudukan Hukum Tenaga Honorer Setelah Berlakunya Undang-Undang Nomor 5 Tahun 2014 Tentang Aparatur Sipil Negara
}

\author{
Honorer Legal Position After Application Law Number 5 Of 2014 Concerning \\ Country Civil Apparatus
}

\author{
Masna \\ Fakultas Ekonomi dan Bisnis Universitas Halu Oleo \\ E-mail:masnamirad@gmail.com \\ La Sensu \\ Pascasarjana Universitas Halu Oleo \\ E-mail: lasensu_march72@yahoo.com \\ Kamaruddin Jafar \\ Pascasarjana Universitas Halu Oleo \\ E-mail: kamaruddinjafar.88@gmail.com
}

\begin{abstract}
Government authority is the implementation of development in all aspects including the appointment of Civil Servants and Appointment of Honorary Staff. With the enactment of Law Number 5 Year 2014 concerning the State Civil Apparatus, the existence of these honorary personnel was subsequently deleted. The term honorary staff does not exist in Law Number 5 of 2014 and is replaced with the term government employee with the use of contracts (PPPK). The method used in this paper is the research method used in this study is a normative research method. Where normative research is legal research, because it is based on the study of legal rules relating to legal facts, and legal position is to test the facts so as to produce several models of normative approaches such as law approaches, case approaches and conceptual approaches according to the needs of this research. The results of the research are the Position of Government Employees with Employment Agreements (PPPK) as an Element of the State Apparatus. As an element of the state civil apparatus, Government Employees with Work Agreements must implement policies determined by the leadership of government agencies and must be free from the influence of intervention from all groups and political parties. Government employees with employment agreements also have the rights to obtain salaries and benefits, leave, protection for life insurance, legal assistance and competence development. Government employees with work agreements obtain different rights from civil servants.
\end{abstract}

Keyword: ASN; Work Agreement; Legal status 


\begin{abstract}
Abstrak: Wewenang pemerintah adalah penyelenggaraan pembangunan di segala aspek termasuk di dalamnya adalah pengangkatan Pegawai Negeri Sipil dan Pengangkatan Tenaga Honorer. Dengan berlakunya Undang-Undang Nomor 5 Tahun 2014 tentang Aparatur Sipil Negara keberadaan tenaga honorer ini kemudian dihapus. Istilah tenaga honorer tidak ada dalam Undang-Undang Nomor 5 tahun 2014 ini dan digantikan dengan istilah pegawai pemerintah dengan penggunaan kontrak (PPPK). Metode yang digunakan dalam penulisan ini adalah metode penelitian yang digunakan dalam penelitian ini adalah metode penelitian normatif. Penelitian normatif merupakan penelitian hukum, sebab didasarkan pada pengkajian aturan hukum yang terkait dengan fakta hukum, serta posisi hukum adalah menguji fakta sehingga menghasilkan beberapa model pendekatan normatif seperti pendekatan undang-undang, pendekatan kasus dan pendekatan konseptual sesuai dengan kebutuhan penelitian ini. Adapun hasil penelitian adalah Kedudukan Pegawai Pemerintah dengan Perjanjian Kerja (PPPK) adalah sebagai Unsur Aparatur Negara. Sebagai unsur aparatur sipil negara maka Pegawai Pemerintah dengan Perjanjian Kerja mesti melaksanakan kebijakan yang ditetapkan oleh pimpinan instansi pemerintah dan harus bebas dari pengaruh intervensi dari semua golongan dan partai politik. Pegawai Pemerintah dengan Perjanjian Kerja juga mempunyai hak-hak mendapatkan gaji dan tunjangan, cuti, perlindungan jaminan kematian, bantuan hukum dan pengembangan kompetensi. Pegawai Pemerintah dengan Perjanjian Kerja memperoleh hakyang berbeda dengan PNS.
\end{abstract}

Kata kunci: ASN; perjanjian kerja; kedudukan hukum

\title{
PENDAHULUAN
}

Pemerintahan merupakan segala kegiatan, fungsi, tugas dan kewajiban yang dijalankan oleh lembaga eksekutif, ${ }^{1}$ yang dalam penyelenggaraannya memerlukan sumber daya baik dana, sarana, prasarana maupun sumber daya manusia. Sumber daya manusia merupakan sumber daya yang paling penting dalam pencapaian tujuan penyelenggaraan pemerintahan. Berkaitan dengan hal tersebut, maka pemerintah perlu melakukan pemenuhan kebutuhan sumber daya manusia yakni melalui aparatur pemerintah yang terdiri dari pejabat negara, pegawai negeri dan dimungkinkan juga tenaga honorer.

Pegawai negeri sebagai bagian dari aparatur negara mempunyai peranan amat penting dalam penyelenggaraan pemerintahan dan pembangunan dalam rangka mencapai tujuan Negara sebagaimana tertuang dalam pembukaan undang-undang Dasar Negara Republik Indonesia Tahun 1945 (selanjutnya disebut UUD NRI Tahun 1945) adalah melindungi segenap bangsa dan seluruh tumpah darah Indonesia, memajukan kesejahteraan umum, mencerdaskan kehidupan bangsa dan melaksanakan ketertiban dunia. Keempat tujuan Negara ini hanya bisa dicapai dengan adanya pembangunan

1 Haryanto, Pemerintahan, Jakarta: Rineka Cipta, 1997, hlm. 2. 
nasional yang dilakukan dengan perencanaan yang matang, realistic, terarah dan terpadu, bertahap, bersungguh-sungguh, berdaya guna dan berhasil guna. ${ }^{2}$

Pengaturan mengenai pegawai negeri sendiri pada awalnya diatur dalam UndangUndang Nomor 8 tahun 1974, sebagaimana telah diubah dengan Undang-Undang Nomor 43 Tahun 1999 tentang Kepegawaian. Undang-Undang tersebut memberikan legitimasi atas kedudukan, peran dan fungsi pegawai negeri yang sangat strategis. Kedudukan pegawai negeri berdasarkan Pasal 3 ayat (1) Undang-Undang Nomor 43 Tahun 1999 merupakan unsur aparatur sipil negara yang bertugas untuk memberikan pelayanan kepada masyarakat secara profesional, jujur, adil dan merata dalam penyelenggaraan tugas negara, pemerintahan dan pembangunan. Mengenai jenis pegawai negeri didasarkan pada Pasal 2 ayat (1) Undang-Undang Nomor 43 Tahun 1999, pegawai negeri dibagi menjadi: (1). Pegawai Negeri Sipil; (2). Anggota Tentara Nasional Indonesia dan (3). Anggota Kepolisian Negara Republik Indonesia.

Selanjutnya, berdasarkan Pasal 2 ayat (3) Undang-Undang Nomor 43 Tahun 1999 pejabat yang berwenang dapat mengangkat pegawai tidak tetap. Pegawai tidak tetap adalah pegawai yang diangkat untuk jangka waktu tertentu guna melaksanakan tugas pemerintahan dan pembangunan yang bersifat teknis profesional dan administrasi sesuai dengan kebutuhan dan kemampuan organisasi. Pegawai tidak tetap tidak berkedudukan sebagai pegawai negeri. Penamaan tenaga honorer mempunyai arti sebagai pegawai di luar PNS dan pegawai lainnya (tenaga kerja), penamaan tenaga honorer merupakan salah satu bentuk antisipasi pemerintah terhadap banyaknya kebutuhan pegawai, namun dibatasi oleh dana APBD dan APBN dalam penggajiannya. ${ }^{3}$ Dalam penyelenggaraan pemerintahan daerah, pemerintah diberi wewenang baik secara terikat maupun wewenang bebas untuk mengambil keputusan untuk melakukan pelayanan umum, wewenang terikat artinya segala tindakan yang dilakukan oleh pemerintah sesuai dengan aturan dasar, sedangkan wewenang bebas artinya pemerintah secara bebas menentukan sendiri mengenai isi dari keputusan yang akan dikeluarkan, karena aturan dasarnya memberi kebebasan kepada penerima wewenang. ${ }^{4}$

Sebagai peraturan pelaksana dari Undang-Undang Nomor 43 Tahun 1999, pemerintah mengeluarkan Peraturan Pemerintah Nomor 48 Tahun 2005 Tentang

2 Lihat Penjelasan Umum Undang-Undang Nomor 8 Tahun 1974 tentang Pokok-Pokok Kepegawaian.

3 Sri Hartini dan Setiajeng Kadarsih, Diktat Hukum Kepegawaian, Purwokerto: Fakultas Hukum Universitas Jenderal Sudirman, 2006, hlm. 26.

4 Sadjijono, Bab-Bab Hukum Administrasi, Yogyakarta: Laksbang Presindo, 2011, hlm. 59-60. 
Pengangkatan Tenaga Honorer Menjadi Calon Pegawai Negeri Sipil yang sekarang sudah diubah dengan Peraturan Pemerintah Nomor 56 Tahun 2012 tentang Perubahan Kedua Atas Peraturan Pemerintah Nomor 48 Tahun 2005 Tentang Pengangkatan Tenaga Honorer Menjadi Calon Pegawai Negeri Sipil yang mengatur mengenai manajemen kepegawaian tenaga honorer. Perekrutan terhadap tenaga honorer secara hukum memang diatur, tetapi masih bersifat terbatas, kewenangan perekrutan tersebut diberikan kepada pemerintah daerah atau pejabat lain yang ditunjuk. Pada dasarnya, kebijakan pengangkatan tenaga honorer diserahkan pada kebutuhan dari masing-masing instansi, namun sejak dikeluarkannya Peraturan Pemerintah Nomor 48 Tahun 2005 tentang Pengangkatan Tenaga Honorer Menjadi Calon Pegawai Negeri Sipil, semua pejabat pembina kepegawaian dan pejabat lain di lingkungan instansi, dilarang mengangkat tenaga honorer atau yang sejenis, kecuali ditetapkan dengan Peraturan Pemerintah.

Pada awalnya tenaga honorer ini dibedakan menjadi 2 (dua) yaitu tenaga honorer kategori I dan tenaga honorer kategori II. ${ }^{5}$ Tenaga honorer kategori I merupakan tenaga honorer yang pembiayaan gajinya dibiayai langsung oleh APBD atau APBN. Tenaga honorer yang masuk kategori I sesuai dengan Peraturan Menteri PAN-RB Tahun 2010, adalah tenaga honorer yang bekerja di instansi pemerintahan mulai tanggal 1 Januari 2005, secara terus menerus. Tenaga honorer kategori II adalah tenaga honorer yang diangkat per 1 Januari 2005 dan tidak mendapat gaji dari APBD atau APBN. Untuk tenaga honorer kategori II, apabila ingin diangkat menjadi Calon Pegawai Negeri Sipil (CPNS) harus mengikuti tes seleksi terlebih dahulu. Selain itu, tenaga honorer yang diangkat setelah dikeluarkannya Peraturan Pemerintah Nomor 48 Tahun 2005 termasuk ke dalam tenaga honorer kategori II (non-kategori).

Undang-Undang Nomor 43 Tahun 1999 dalam implementasinya belum mampu menjawab tantangan dan tuntutan yang dihadapi birokrasi selama ini. Reformasi birokrasi baru sebatas remunerasi dan belum pada perubahan mindset dan culture set birokrasi. Oleh karena itu Undang-Undang Nomor 43 Tahun 1999 tentang Pokok-Pokok Kepegawaian sudah tidak sesuai lagi dengan tuntutan nasional dan tantangan global saat ini. Atas dasar hal tersebut, dalam rangka reformasi birokrasi sebagai upaya untuk melakukan pembaharuan dan perubahan mendasar terhadap sistem penyelenggaraan

5 Penjelasan Umum Peraturan Pemerintah Nomor 56 Tahun 2012 Tentang Perubahan Kedua Peraturan Pemerintah Nomor 48 Tahun 2005 Tentang Pengangkatan tenaga Honorer Menjadi Calon Pegawai Negeri Sipil. 
pemerintahan terutama menyangkut aspek-aspek kelembagaan, ketatalaksanaan dan sumber daya manusia agar birokrasi mampu mewujudkan tujuan negara, maka pemerintah melakukan penggantian peraturan yang mengatur mengenai pegawai negeri yakni diganti dengan Undang-Undang Nomor 5 Tahun 2014 tentang Aparatur Sipil Negara, sehingga Undang-Undang Nomor 8 Tahun 1974 tentang Pokok-Pokok Kepegawaian sebagaimana telah diubah dengan Undang-Undang Nomor 43 Tahun 1999 tentang perubahan atas Undang-Undang Nomor 8 Tahun 1974 tentang Pokok-Pokok Kepegawaian dicabut dan dinyatakan tidak berlaku. Undang-Undang Aparatur Sipil Negara merupakan salah satu peraturan yang menjadi titik tolak untuk berubahnya wajah birokrasi di Indonesia.

Selain itu dalam undang-undang ini tidak akan ada lagi di atur PNS Pusat dan Daerah, yang ada hanya PNS dan Pegawai Pemerintah dengan Perjanjian Kerja (selanjutnya disebut PPPK). ${ }^{6}$ Semuanya sama menjadi Aparatur Sipil Negara dan memiliki hak yang sama dalam pembinaan, pendidikan, pelatihan serta kesempatan yang sama dalam penjenjangan jabatan baik pusat maupun daerah. Di dalam ketentuan Pasal 1 angka 2 Undang-Undang Aparatur Sipil Negara, dinyatakan bahwa Pegawai Aparatur Sipil Negara (selanjutnya disebut sebagai Pegawai ASN) adalah PNS dan PPPK yang diangkat oleh pejabat Pembina kepegawaian dan diserahi tugas dalam suatu jabatan pemerintahan atau diserahi tugas negara lainnya dan digaji berdasarkan peraturan perundang-undangan. Di dalam Pasal 2 huruf a, Pasal 2 huruf j, Pasal 6, Pasal 61, Pasal 66 ayat (2) dan Pasal 137 Undang-Undang Aparatur Sipil Negara hanya mengatur status PNS dan PPPK, namun tidak mengatur mengenai status tenaga honorer.

Dengan tidak diaturnya keberadaan tenaga honorer dalam klasifikasi pegawai ASN mengakibatkan ketidakjelasan bagi status dan posisi tenaga honorer apakah nantinya otomatis diangkat menjadi PNS maupun PPPK. Hal tersebut memberikan gambaran terjadinya ketidakpastian hukum akibat tidak adanya pengaturan mengenai kedudukan tenaga honorer ini tentu mengakibatkan pula mengambangnya keadilan yang akan diterima tenaga honorer berkaitan dengan hak dan kewajibannya, padahal dalam praktiknya apabila membandingkan antara PNS dengan kewajiban yang dibebankan kepada tenaga honorer tidak jauh berbeda. Tenaga honorer memiliki fungsi yang sama

6 Pasal 135 Undang-Undang Nomor 5 Tahun 2014 Tentang Aparatur Sipil Negara. 
dengan PNS yaitu menjalankan pelayanan publik kepada masyarakat, akan tetapi hak di antara keduanya sangat jauh berbeda.

Berdasarkan latar belakang tersebut, dimana dalam Undang-Undang Nomor 5 Tahun 2014 tentang Aparatur Sipil Negara tidak mengatur keberadaan tenaga honorer dalam klasifikasi pegawai aparatur sipil negara menyebabkan kehilangan kepastian hukum dan menciptakan ketidakadilan bagi tenaga honorer, untuk itu penulis merasa tertarik melakukan analisis terhadap permasalahan tersebut yang dituangkan dalam pembahasan tesis yang berjudul “Kedudukan Hukum Tenaga Honorer Setelah Berlakunya Undang-Undang Nomor 5 Tahun 2014 Tentang Aparatur Sipil Negara. Tulisan ini hendak menjawab dua permasalahan, yakni pertama, Bagaimana Kedudukan Hukum Tenaga Honorer Setelah Berlakunya Undang-Undang Nomor 5 Tahun 2014 Tentang Aparatur Sipil Negara?, kedua, Bagaimana Kekuatan Hukum Perjanjian Kontrak Kepegawaian terhadap Kedudukan Hukum Pemerintah dengan Perjanjian Kerja (PPPK)?

\section{METODE PENELITIAN}

Jenis penelitian/pendekatan yang digunakan oleh penulis adalah penelitian hukum normative empiric. Penelitian hukum normative menurut Peter Mahmud Marzuki ${ }^{7}$ yaitu penelitian hukum yang dilakukan dengan pendekatan undang-undang (statute approach), pendekatan kasus (case approach), pendekatan historis (historical approach), pendekatan komparatif (comparative approach), dan pendekatan konseptual (conceptual approach). Sedangkan normative empiris, ${ }^{8}$ yakni penelitian yuridis dilakukan dengan cara meneliti bahan pustaka yang merupakan data sekunder dan juga disebut penelitian kepustakaan. Penelitian hukum empiris dilakukan dengan cara meneliti di lapangan yang merupakan data primer.

\section{ANALISIS DAN PEMBAHASAN}

\section{Kedudukan Hukum Pegawai Pemerintah Dengan Perjanjian Kerja Setelah Berlakunya Undang-Undang Nomor 5 Tahun 2014}

Istilah "negara hukum" terdiri dari dua kata yaitu "negara" dan "hukum" kata "negara" berasal dari bahasa Sangsekerta dan mulai terpakai sejak abad ke-5 dalam ketatanegaraan

Peter Mahmud Marzuki, Penelitian Hukum, Jakarta: Kencana Prenada Media Group, 2005, hlm. 93.

8 Ronny Hanitijo Soemitro, Metode Penelitian Hukum dan Jurimetri, Jakarta: Ghalia Indonesia, 1990, hlm. 36. 
Indonesia. Awal mulanya, kata tersebut digunakan untuk menamai Negara Tarum ( Tarum Negara) di bawah kepala Negara Purnawarman di Jawa Barat. ${ }^{9}$ Hugo De Grrot (1583-1645) mengatakan bahwa negara adalah ibarat suatu perkakas yang di buat oleh manusia untuk melahirkan keberuntungan dan kesejahteraan umum. ${ }^{10}$ Bellefroid mengatakan bahwa negara itu suatu persekutuan hukum yang menempati suatu wilayah untuk selamalamanya dan yang dilengkapi dengan suatu kekuasaan tertinggi untuk menyelenggarakan kemakmuran rakyat sebesar-besarnya. ${ }^{11}$

Oleh karena itu, kedudukan hukum tenaga honorer sudah seharusnya mendapat kepastian hukumnya, sebagaimana yang telah dinyatakan dalam konstitusi negara bahwa Indonesia adalah negara hukum. Selain itu juga, dalam rangka manajemen kepegawaian adalah untuk mencapai suatu tujuan yang ada hubungannya dengan individu dengan organisasi, dalam upayanya mewujudkan Governance. Pengertian Governance dapat diartikan sebagai cara mengelola urusan-urusan publik. Sedangkan UNDP (United Nation Development Programme) mendefinisikan governance sebagai "the exercise of political, economic, and administrative authority to monage a nation affair at all levels". Dalam hal ini , World Bank lebih menekankan pada cara pemerintah mengelola sumber daya sosial dan ekonomi untuk kepentingan pembangunan masyarakat, sedangkan UNDP (United Nations Development Programme) lebih menekankan pada aspek politik, ekonomi dan administrasi dalam pengelolaan negara. ${ }^{12}$

Jadi, terselenggaranya good govermance merupakan prasyarat bagi setiap pemerintah untuk mewujudkan aspirasi masyarakat dan mencapai tujuan serta cita-cita bangsa bernegara. Dalam rangka itu diperlukan perkembangan dan penerapan sistem pertanggungjawaban yang tepat, jelas dan legitimitas, sehingga penyelenggaraan pemerintahan dan pembangunan dapat berlangsung secara berdaya guna, berhasil guna, bersih dan bertanggungjawab, serta bebas dan korupsi, kolusi dan nepotisme.

Maka, Kedudukan Pegawai Pemerintah dengan Perjanjian Kerja (PPPK) adalah sebagai unsur aparatur negara (Pasal 8 Undang-Undang Nomor 5 Tahun 2014 tentang Aparatur Sipil Negara). Sebagai unsur aparatur sipil negara maka Pegawai Pemerintah dengan Perjanjian Kerja (PPPK) mesti melaksanakan kebijakan yang ditetapkan oleh pimpinan instansi pemerintah dan harus bebas dari pengaruh intervensi dari semua

9 Didi Nazmil Yuas, Konsepsi Negara Hukum, Padang: Angkasa Raya, 1992, hlm. 18.

10 Samidjo, Ilmu Negara, Bandung: Armico, 1986, hlm. 28.

11 Ibid, hlm. 32.

12 A.W.Soichin, Analisis Kebijakan, Edisi Kedua, Jakarta: Bumi Aksara, 2005, hlm. 23. 
golongan dan partai politik. Pegawai Pemerintah dengan Perjanjian Kerja (PPPK) juga mempunyai hak-hak sebagai berikut (Pasal 22):

(a). Gaji dan tunjangan, memberikan penggajian dan tunjangan dijelaskan bahwa pemerintah wajib memberikan gaji yang adil dan layak (Pasal 101 Ayat 1). Gaji yang diberikan pemerintah diberikan berdasarkan beban kerja, tanggung jawab jabatan, dan risiko. Di dalam Undang-Undang Nomor 5 Tahun 2014 tentang Aparatur Sipil Negara ini tidak dijelaskan secara rinci mengenai tunjangan Pegawai Pemerintah dengan Perjanjian Kerja (PPPK), namun pada Pasal 101 Ayat (4) dijelaskan bahwa Pegawai Pemerintah dengan Perjanjian Kerja (PPPK) menerima tunjangan sesuai Peraturan Perundang-Undangan, (b).Cuti; (c).Perlindungan, perlindungan yang diberikan pemerintah terhadap Pegawai Pemerintah dengan Perjanjian Kerja (PPPK) adalah (Pasal 92 ayat (1) UU ASN): Jaminan kesehatan; Jaminan kecelakaan kerja; Jaminan kematian; Bantuan hukum; dan (d). Pengembangan kompetensi, pengembangan kompetensi terhadap Pegawai Pemerintah dengan Perjanjian Kerja (PPPK) diadakan setiap tahun oleh instansi pemerintah. Pengembangan kompetensi merupakan salah satu dasar untuk perjanjian kerja selanjutnya (Pasal 102 Ayat 1,2 dan 3 Undang-Undang Nomor 5 Tahun 2014 tentang Aparatur Sipil Negara).

Pemutusan hubungan perjanjian kerja dapat dilakukan oleh instansi pemerintah yang dikarenakan: (1).Jangka waktu perjanjian kerja berakhir; (2). Meninggal dunia; (3)Atas permintaan sendiri; (4). Perampingan organisasi; (5). Tidak cakap jasmani dan/atau rohani sehingga tidak dapat menjalankan tugas dan kewajiban sebagai PPPK; (6). Melakukan tindak pidana; (7). Pelanggaran disiplin berat PPPK. Kemudian, ketentuan lebih lanjut mengenai Pegawai Pemerintah dengan Perjanjian Kerja akan diatur dalam Peraturan Pemerintah seperti syarat menjadi PPPK, Metode Seleksi PPPK, Besaran Gaji dan Tunjangan PPPK, serta hal-hal terkait Pegawai PPPK. Dalam memberikan penggajian dan tunjangan dijelaskan bahwa pemerintah wajib memberikan gaji yang adil dan layak (Pasal 101 Ayat 1). Gaji yang diberikan pemerintah diberikan berdasarkan beban kerja, tanggung jawab jabatan, dan risiko pekerjaan. Di dalam Undang-Undang Aparatur Sipil Negara ini dijelaskan secara rinci mengenai tunjangan Pegawai Pemerintah dengan Perjanjian Kerja (PPPK), namun pada Pasal 101 Ayat (4) Undang-Undang Aparatur Sipil Negara dijelaskan bahwa Pegawai Pemerintah dengan Perjanjian Kerja (PPPK) menerima tunjangan sesuai peraturan perundang-undangan.

\section{Kekuatan Hukum Perjanjian Kontrak Kepegawaian terhadap Kedudukan Hukum Pemerintah dengan Perjanjian Kerja (PPPK)}

Pegawai Negeri Sipil mempunyai peranan yang amat penting sebab pegawai negeri merupakan unsur aparatur negara untuk menyelenggarakan pemerintahan dan 
pembangunan dalam rangka pencapaian tujuan negara. Pemerintahan negara RI menganut sistem fundamental, ini terwujud dengan adanya berbagai departemen, lembaga pemerintah non departemen yang masing-masing melaksanakan tugas pokok dan fungsi yang berbeda, tapi mempunyai tujuan yang sama yaitu pencapaian tujuan nasional. Dengan demikian bisa dilihat dari tugas yang di emban oleh setiap pegawai negeri maka mereka mempunyai peredaran fungsi yang sesuai dengan instansi tempat mereka bekerja. Fungsi pegawai negeri erat hubungannya dengan kedudukan pegawai negeri sipil dimana fungsi pegawai negeri sebagai unsur penggerak organisasi atau lembaga pemerintahan, peraturan dengan terciptanya ketatalaksanaan yang tertib, efektif dan efisien serta mengolah kelengkapan milik pemerintah atau negara.

Pada dasarnya rekrutmen dilakukan untuk mengisi kebutuhan organisasi akan tenaga kerja/karyawan yaitu untuk menduduki jabatan-jabatan yang ada dalam organisasi yang masih kosong. Terkait dengan rekrutmen dalam Peraturan Pemerintah Nomor 98 Tahun 2000 tentang pengadaan PNS disebutkan bahwa pengadaan Pegawai Negeri Sipil dilakukan mulai dari perencanaan, pengumuman, pelamaran, penyaringan, pengangkatan Calon Pegawai Negeri Sipil sampai dengan pengangkatan menjadi Pegawai Negeri Sipil. Pelaksanaan rekrutmen dan seleksi merupakan tugas yang sangat penting, krusial dan membutuhkan tanggung jawab yang besar. Hal ini karena kualitas sumber daya manusia yang akan di gunakan sangat tergantung pada bagaimana prosedur rekrutmen dilaksanakan.

Langkah-langkah dalam rekrutmen pegawai di pengaruhi oleh aturan-aturan yang berlaku di setiap perusahaan, organisasi ataupun instansi. Perbedaan tercermin dari nilainilai apa yang menjadi panutan. Suatu perusahaan berbeda dengan yang lain dan akan mempengaruhi setiap kebijakan penerimaan atau rekrutmen pegawai baru. Kebijakankebijakan yang bersifat politis dari kalangan birokrat/pengusaha juga akan mempengaruhi perekrutmen. Pegawai juga merupakan modal pokok dalam suatu organisasi, baik itu organisasi pemerintah maupun organisasi swasta, dikatakan bahwa pegawai merupakan modal pokok dalam suatu organisasi dalam mencapai tujuannya tergantung pada pegawai yang memimpin dalam melaksanakan tugas-tugas yang ada dalam organisasi tersebut. Pegawai yang telah memberikan tenaga maupun pikirannya dalam melaksanakan tugas ataupun pekerjaan, baik itu organisasi pemerintah maupun organisasi swastakan mendapat imbalan sebagai balas jasa atas pekerjaan yang telah dikerjakan. Dapat ditarik suatu kesimpulan bahwa pegawai sebagai tenaga kerja atau yang 
menyelenggarakan pekerjaan perlu digerakkan sehingga mereka mampu bekerja secara efektif.

Undang-Undang Nomor 43 Tahun 1999 Tentang Pokok-Pokok Kepegawaian pada Pasal 1 ayat (10) menyebutkan bahwa PNS adalah setiap warga Negara RI yang telah memenuhi syarat yang ditentukan, diangkat oleh pejabat yang berwenang dan diserahi tugas dalam suatu jabatan negeri, atau diserahi tugas lainnya, dan digaji berdasarkan peraturan perundang-undangan yang berlaku. Undang-Undang Nomor 8 Tahun 1974 Pasal 5 juga tercantum bahwa Pegawai Negeri Sipil adalah pelaksana peraturan perundang-undangan, oleh sebab itu wajib berusaha agar setiap peraturan perundangundangan ditaati oleh masyarakat, berhubung dengan itu Pegawai Negeri Sipil berkewajiban untuk memberikan contoh yang baik dalam menaati dan melaksanakan segala peraturan perundang-undangan yang berlaku.

Undang-Undang Nomor 5 Tahun 2014 Pasal 1 ayat (3) menyebutkan bahwa (Pegawai Negeri Sipil yang selanjutnya diangkat PNS adalah warga negara Indonesia yang memenuhi syarat tertentu, diangkat sebagai Pegawai ASN secara tetap oleh pejabat pembina kepegawaian untuk menduduki jabatan pemerintah". Adapun jenis pegawai di undang-undang yang lama disebutkan bahwa pegawai itu terdiri dari Pegawai Negeri Sipil, Anggota Tentara Nasional Indonesia dan anggota Kepolisian Negara Republik Indonesia, Pegawai Negeri Sipil. Sedangkan di dalam Undang-Undang ASN disebutkan bahwa pegawai hanya terdiri dari Pegawai Negeri Sipil dan Pegawai Pemerintah dengan Perjanjian Kerja. Di samping Pegawai Negeri, pejabat yang berwenang dapat mengangkat pegawai negeri tidak tetap, yang diangkat untuk jangka waktu tertentu guna melaksanakan tugas pemerintahan dan pembangunan sesuai dengan kebutuhan dan kemampuan organisasi.

Selain itu Pegawai Negeri Sipil memiliki tiga fungsi yang melekat padanya. Fungsi tersebut adalah sebagai abdi negara, Aparatur Pemerintah serta pelayan masyarakat. Dalam kedudukan sebagai Abdi Negara seorang Pegawai Negeri Sipil adalah warga negara yang harus tetap menunjukkan pengabdiannya. Setelah diterbitkan Undang-Undang ASN menimbulkan permasalahan, karena di dalam Undang-Undang ASN tidak menyebutkan tentang Pegawai Honorer dalam jenis pegawai ASN. Karena, Undang-Undang ASN menyebutkan bahwa pegawai ASN hanya PNS dan PPPK. Jadi dengan adanya UU ASN tersebut tidak ada kejelasan atau kepastian bagi para pegawai honorer yang sudah dari dulu sebelum diterbitkannya UU ASN tersebut dan hingga sekarang belum di angkat. Maka, 
eksistensi pegawai honorer daerah diakui secara formal dalam Undang-Undang Nomor 43 tahun 1999 tentang perubahan Atas Undang-Undang Nomor 8 Tahun 1974 tentang PokokPokok Kepegawaian Pasal 2 ayat (3) dan di implementasikan dalam struktur sumber daya aparatur Indonesia, yang berfungsi membantu pelaksanaan tugas-tugas pemerintah dan pelayanan pada masyarakat.

Pegawai Negeri Sipil merupakan warga Negara Indonesia yang memenuhi syarat tertentu, diangkat sebagai pegawai ASN yang diangkat sebagai pegawai tetap oleh Pejabat Pembina Kepegawaian untuk menduduki jabatan pemerintahan dan memiliki nomor induk pegawai secara nasional. Pengertian ini tidak jauh berbeda dengan pengertian sebagaimana yang terdapat dalam undang-undang sebelumnya. Sedangkan Pegawai pemerintah dengan Perjanjian Kerja (PPPK) yaitu warga Negara Indonesia yang memenuhi syarat tertentu, yang diangkat berdasarkan perjanjian kerja untuk jangka waktu tertentu dalam rangka melaksanakan tugas pemerintahan.

Oleh karena itu, pemerintah seharusnya memperhatikan asas legalitas yang merupakan salah satu prinsip utama dalam setiap penyelenggaraan pemerintah dan Negara, secara normatif bahwa setiap tindakan pemerintah harus berdasarkan peraturan perundang-undangan atau berdasarkan pada kewenangan yang dianut setiap Negara hukum. Dengan penerapan asas legalitas ini oleh pemerintah maka tindakan yang dilakukan akan jelas dan memiliki kepastian hukum karena asas legalitas menjadi dasar legitimasi tindakan pemerintah sehingga persamaan perlakuan pada setiap orang terutama pegawai, baik itu yang berstatus pegawai negeri maupun tenaga honorer akan terwujud hingga hak asasi mereka sebagai pegawai akan terjaga.

Setiap manusia berhak atas pekerjaan, penghidupan yang layak, dihargai dengan diperlakukan secara adil dalam kehidupannya, karena manusia sebagai makhluk ciptaan tuhan memiliki hak asasi yang harus dihormati oleh siapa saja. Hak Asasi Manusia (HAM) adalah hak yang dimiliki, diperoleh dan dibawa bersama dengan kelahiran atau kehadirannya di dalam kehidupan masyarakat. Hak asasi manusia merupakan hak yang melekat pada manusia sebagai makhluk Tuhan oleh karena itu menjadi kewajiban semua orang untuk menghormati , menjunjung tinggi dan melindungi HAM. Dengan berpedoman pada asas legalitas maka tidak akan terjadi pelanggaran terhadap HAM, sebab itu pemerintah daerah dalam mengelola aparaturnya harus berdasarkan pada peraturan yang ada. Sebab, di keluarkannya peraturan Pemerintah Nomor 48 Tahun 2005 dengan alasan untuk lebih memprioritaskan tenaga honorer menjadi CPNS. Hal ini berlanjut dengan 
dikeluarkannya Peraturan Pemerintah Nomor 43 Tahun 2007 yang berisi perubahan pertama dari Peraturan Pemerintah Nomor 48 Tahun 2005 dan perubahan kedua dengan keluarnya Peraturan Pemerintah Nomor 56 Tahun 2012.

Bila merujuk kepada syarat sahnya perjanjian kerja menurut undang-undang, maka terlebih dahulu disepakati bahwa untuk pembuatan perjanjian ini ada syarat-syarat sah dari perjanjian. Dengan terpenuhinya syarat-syarat ini maka suatu perjanjian berlaku sah. Syarat ini menurut R. Subekti terdapat pada Pasal 1320 KUH Perdata sebagai berikut: (1). Kesepakatan mereka yang mengikat diri. Persetujuan hendak yang diberikan sifatnya harus bebas dan murni artinya betul-betul atas kemauan sendiri tidak ada paksaan dari pihak mana pun dalam persetujuan dan tidak ada kekhilafan dan penipuan; (2). Cakap untuk membuat suatu perjanjian, menurut Pasal 1329 KUH Perdata menyebutkan bahwa setiap orang adalah cakap untuk membuat suatu perikatan, jika oleh Undang-Undang dikatakan tidak cakap. ${ }^{13}$ Mengenai orang yang dianggap tidak cakap untuk membuat suatu perjanjian di atur dalam Pasal 1330 KUH Perdata yaitu: (a). Orang-orang yang belum dewasa; (b). Mereka yang ditaruh di bawah pengampunan; dan (c). Orang-orang perempuan, dalam hal-hal yang ditetapkan oleh Undang-Undang. Dan pada umumnya semua orang kepada siapa Undang-Undang telah melarang membuat perjanjianperjanjian tertentu, kemudian (3). Suatu hal tertentu, dimana untuk mengetahui apa yang dimaksud dengan "hal tertentu" (cenbepaald onderwer), perlu kita lihat ketentuan yang terdapat dalam Pasal 1313 KUH Perdata yang mengatakan bahwa: “ Suatu perjanjian harus mempunyai pokok suatu barang yang paling sedikit ditentukan jenisnya". Maksudnya adalah bahwa objek perjanjian harus tentu sekalipun masing-masing objek tidak harus secara individual tertentu; dan terakhir (4). Suatu sebab yang halal. Bahwa perjanjian tanpa sebab yang halal akan berakibat bahwa perjanjian tersebut akan batal demi hukum. Sedangkan, pengertian sebab (causa) di sini adalah tujuan dari perjanjian, apa yang menjadi isi, kehendak dibuatnya suatu perjanjian. KUH Perdata menetapkan bahwa untuk sahnya perjanjian, selain ada causa yang halal (justa causa), undang-undang tidak memberikan perumusan yang jelas.

Selanjutnya ada pula beberapa syarat perjanjian atau kontrak yang berlaku umum tetapi di atur dalam Pasal 1320 KUH Perdata, yaitu sebagai berikut: (1). Harus dilakukan dengan itikad baik, artinya kedua belah pihak yang melakukan perjanjian harus

13 R. Subekti, Hukum Perjanjian, Jakarta: Intermasa, 1994, hlm. 31. 
melaksanakan isi perjanjian dengan suka rela dan tanpa ada paksaan, serta dengan itikad yang benar-benar mau melaksanakan isi perjanjian yang disepakati; (2). Kontrak tidak boleh bertentangan dengan kebiasaan yang berlaku, artinya isi perjanjian itu tidak dibenarkan bertentangan dengan kebiasaan yang berlaku ditengah-tengah masyarakat, tidak boleh bertentangan dengan kondisi yang ada dalam masyarakat; (3). Kontrak harus dilakukan berdasarkan keputusan, artinya perjanjian yang telah disepakati harus mengikuti asas yang tidak bertentangan dengan ketentuan yang berlaku dalam masyarakat, tidak boleh melanggar hak-hak masyarakat; dan (4). Kontrak tidak boleh melanggar kepentingan umum, artinya kontrak yang dibuat tersebut tidak dibenarkan bertentangan dengan kepentingan yang ada dalam masyarakat, tidak boleh menimbulkan kerugian dalam masyarakat.

Maka, perjanjian kerja itu sama halnya dengan kontrak, dimana ada hal-hal yang harus disepakati dan harus ditaati terkait dengan perjanjian tersebut, misalnya kedudukan hanya sementara dan akan diperpanjang sesuai dengan peraturan, hanya saja sudah ada jaminan hukum yang mengaturnya. Misalnya perjanjian kerjanya ada jangka waktu yang telah ditentukan, tetapi bias diperpanjang kembali tergantung poin-poin dalam perjanjian tersebut dan dalam SK tersebut ada aturan yang tidak boleh dilanggar, kalau dilanggar akan dikenakan sanksi.

Jadi, kedudukan pegawai pemerintah dengan perjanjian Kerja (PPPK) adalah sebagai unsur Aparatur Sipil Negara maka pegawai pemerintah dengan Perjanjian Kerja (PPPK) harus melaksanakan kebijakan yang ditetapkan oleh pimpinan instansi pemerintah dan harus bebas dari pengaruh intervensi dari semua golongan dan partai politik. Pegawai pemerintah dengan Perjanjian Kerja (PPPK) sebagai pegawai ASN juga tidak boleh terlibat dengan praktik korupsi, kolusi, dan nepotisme (KKN). Keharusan PPPK sebagai pegawai ASN dalam melaksanakan kebijakan yang ditetapkan oleh instansi pemerintah dan bebas dari intervensi semua golongan serta bebas dari praktik KKN di atur dalam Pasal 9 UU ASN.

\section{KESIMPULAN}

Kedudukan dan status tenaga honorer dengan adanya pergantian Undang-Undang Nomor 43 tahun 1999 tentang Perubahan atas Undang-Undang Nomor 8 Tahun 1974 Tentang Pokok-Pokok Kepegawaian dan Undang-Undang Nomor 5 Tahun 2014 tentang Aparatur Sipil Negara membuat kedudukan tenaga Honorer menjadi hilang. Jika sebelumnya ada 
ketentuan peraturan untuk mengangkat tenaga honorer yang dapat dijadikan sebagai calon pegawai negeri sipil, maka dalam ketentuan peraturan yang baru kedudukan tenaga honorer menjadi hilang yang digantikan dengan Pegawai Pemerintah dengan Perjanjian Kerja. Tenaga honorer yang ada saat ini tetap berkedudukan sebagai tenaga honorer sampai menunggu adanya peraturan pemerintah yang mengatur lebih lanjut. Kedudukan hukum Pegawai Pemerintah dengan Perjanjian Kerja yaitu sebagai unsur Aparatur Sipil Negara yang bebas dari intervensi semua golongan. Pegawai pemerintah dengan Perjanjian kerja memiliki kewajiban yang sama dengan Pegawai Negeri sipil sebagai Pegawai Aparatur Sipil Negara tapi tidak memiliki kedudukan yang sama dengan PNS, status PPPK hanya diikat dengan perjanjian kontrak. Namun Pegawai Pemerintah dengan Perjanjian Kerja memperoleh hak yang berbeda dengan PNS. Perbedaan hak tersebut terletak pada hak memperoleh fasilitas, jaminan pensiun dan jaminan hari tua yang tidak diperoleh oleh Pegawai Pemerintah dengan Perjanjian kerja (PPPK).

\section{Daftar Pustaka}

\section{Buku}

Hartini, Sri dan Setiajeng Kadarsih, Diktat Hukum Kepegawaian, Purwokerto: Fakultas Hukum Universitas Jenderal Sudirman, 2006.

Haryanto, Pemerintahan, Jakarta: Rineka Cipta, 1997.

Marzuki, Peter Mahmud, Penelitian Hukum, Jakarta: Kencana Prenada Media Group, 2005. Sadjijono, Bab-Bab Hukum Administrasi, Yogyakarta: Laksbang Presindo, 2011.

Samidjo, Ilmu Negara, Bandung: Armico, 1986.

Soemitro, Ronny Hanitijo, Metode Penelitian Hukum dan Jurimetri, Jakarta: Ghalia Indonesia, 1990.

Soichin, A. W., Analisis Kebijakan, Edisi Kedua, Jakarta: Bumi Aksara, 2005.

Subekti, R., Hukum Perjanjian, Jakarta: Intermasa, 1994.

Yuas, Didi Nazmil, Konsepsi Negara Hukum, Padang: Angkasa Raya, 1992.

\section{Peraturan Perundang-undangan}

Undang-Undang Dasar Negara Republik Indonesia 1945

Undang-Undang Nomor 8 Tahun 1974 tentang Pokok-Pokok Kepegawaian.

Undang-Undang Nomor 5 Tahun 2014 Tentang Aparatur Sipil Negara. 
Peraturan Pemerintah Nomor 56 Tahun 2012 Tentang Perubahan Kedua Peraturan Pemerintah Nomor 48 Tahun 2005 Tentang Pengangkatan tenaga Honorer Menjadi Calon Pegawai Negeri Sipil. 